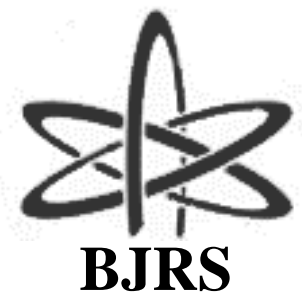

BRAZILIAN JOURNAL

$\mathrm{OF}$

RADIATION SCIENCES

07-02A (2019) 01-16

\title{
Bentonite and Montmorillonite maturation with Águas de Lindóia, Peruíbe, and Poços de Caldas waters
}

\author{
Torrecilha ${ }^{a}$ J. K., Lazzerini ${ }^{\mathrm{b}}$ F. T., Silva ${ }^{\mathrm{a}}$ P. S. C. \\ anstituto de Pesquisas Energéticas e Nucleares, 05508-000, São Paulo, SP, Brazil \\ ${ }^{b}$ Universidade Federal do Espírito Santo, UFES, Brasil. \\ jeffkoy@hotmail.com
}

\begin{abstract}
This study aims to characterize the artificial peloid obtained by maturing bentonite and montmorillonite with Águas de Lindóia, Poços de Caldas, and Peruíbe waters for three months. The pH, moisture, organic matter content, loss on ignition and swelling power of matured and non-matured samples were measured for physicochemical characterization. The elemental concentration was determined by instrumental neutron activation analysis. Results showed that $\mathrm{pH}$, moisture $(\%)$ and LOI $(\%)$ at $1000{ }^{\circ} \mathrm{C}$ did not change after maturation for all samples and an increase of the organic matter (\%) was noted for all samples, mainly in the peloids treated with Peruíbe seawater. The concentration of $\mathrm{As}, \mathrm{Ba}, \mathrm{Br}, \mathrm{Ca}, \mathrm{Ce}, \mathrm{Co}, \mathrm{Cr}, \mathrm{Cs}, \mathrm{K}, \mathrm{La}, \mathrm{Na}, \mathrm{Yb}$, and $\mathrm{Zn}$ have changed after the maturation process in both clays and the $\mathrm{Br}$ and $\mathrm{Na}$ concentrations have changed in both clays when matured with seawater from Peruíbe.
\end{abstract}

Keywords: Bentonite maturation, Montmorillonite maturation, Peloids.

ISSN: 2319-0612

Accepted: 2019-01-03 


\section{INTRODUCTION}

Peloids have been used as thermal therapeutic agents in many spas and thermal centers since ancient times. The term 'peloid' is used to refer to different kinds of sediments or deposits whose composition includes mainly silicates (micas, clays, feldspars, etc.), but also carbonates, sulphates, sulphides and variable amounts of organic substances. When mixed with sea or minero-medicinal water these minerals form pastes or poultices for thermal uses [1]. It can be applied to different parts of the body or on the whole body by means of masks and poultices, or even by partially, or totally bathing the body, for therapeutic or cosmetic purposes.

During the peloid formation, it passes by a maturation process, in which its characteristic greasiness is acquired due to the components mixing and the growth of organic constituents, that arises from biological activity [2,3]. Peloids are formed naturally in a wide range of environments all over the world and in Brazil, only the Peruíbe Black Mud (PBM) had been studied and was well chemically characterized [4]. Nevertheless, the use of these natural peloids in spas and thermal therapeutic centers for cosmetic and medicinal purposes can lead to a depletion of this natural resource over the time [5].

This study aims to characterize the elemental composition of the peloids artificially obtained by the maturation process of mixing commercial bentonite and montmorillonite with minero-medicinal water from Águas de Lindóia and Poços de Caldas cities, located in the countryside of São Paulo and Minas Gerais states, respectively, Southeast, Brazil, and seawater from Peruíbe city, São Paulo state. The bentonites have been used as peloid for their high swelling index, high plasticity, water limit and specific heat that improve the quality of the pastes [6]. The montmorillonite was used because it is largely used in aesthetic and therapeutic treatments such as facial masks and antiinflammatory arthritic or rheumatic processes. The Águas de Lindóia water is a low radioactive, hypo-saline water that emerges at $37{ }^{\circ} \mathrm{C}$ and is commonly used for rheumatic and skin affections treatment. The Poços de Caldas water is sulphurous reaching the surface at $45^{\circ} \mathrm{C}$ and is commonly used for rheumatism treatments. Seawater, from the city of Peruíbe, was used because of its use in thalassotherapy treatment. 


\section{MATERIALS AND METHODS}

The bentonite and montmorillonite clay samples were acquired in the formal market and for the maturation process, samples were left in contact with running water in Águas de Lindóia and Poços de Caldas spas and in standing water in Peruíbe at the "Complexo Thermal da Lama Negra de Peruíbe." After three months of maturation, the samples were collected (BAL, BPC and BPE for bentonite maturation in Águas de Lindóia, Poços de Caldas and Peruíbe waters, respectively and MAL, MPC and MPE for montmorillonite maturation in Águas de Lindóia, Poços de Caldas and Peruíbe waters, respectively), dried, transferred to a mortar, crushed, sieved to a grain size smaller than 150 mesh. About $150 \mathrm{mg}$ of each sample together with Certified Reference Materials (CRMs) Syenite, Table Mountain STM-2 from the United States Geological Survey (USGS), Estuarine Sediment, SRM 1646a, from National Institute of Standards and Technology (NIST) and filter paper sheets pipetted with standard solution from SPEX CertiPrep were prepared by packing them in polyethylene bags for irradiation.

Samples and CRMs were irradiated in the IEA-R1 reactor at IPEN under a neutron flux of $10^{12} \mathrm{~cm}^{-2} \mathrm{~s}^{-1}$, during 8 hours, to determine the elements $\mathrm{As}, \mathrm{Ba}, \mathrm{Br}, \mathrm{Ce}, \mathrm{Co}, \mathrm{Cr}, \mathrm{Cs}, \mathrm{Eu}, \mathrm{Fe}, \mathrm{He}, \mathrm{K}$, $\mathrm{La}, \mathrm{Lu}, \mathrm{Na}, \mathrm{Nd}, \mathrm{Rb}, \mathrm{Sb}, \mathrm{Sc}, \mathrm{Se}, \mathrm{Sm}, \mathrm{Ta}, \mathrm{Tb}, \mathrm{Th}, \mathrm{U}, \mathrm{Yb}$, and $\mathrm{Zn}$ by instrumental neutron activation analysis (INAA). The induced activity was measured by gamma spectrometry performed by using an EG\&G Ortec High Purity Germanium (HPGe) detector and associated electronic, with a resolution of $1.9 \mathrm{keV}$ and $2.04 \mathrm{keV}$ for ${ }^{57} \mathrm{Co}$ and ${ }^{60} \mathrm{Co}$, respectively. Two series of counting were made: the first, after 1-week decay; and the second, after 15-20 days. The spectra analysis was done by using the in-house software VISPECT2, and the calculations were done by using an electronic spreadsheet.

For physicochemical characterization, wet samples were treated sequentially: a) at $105{ }^{\circ} \mathrm{C}$, for $24 \mathrm{~h}$ to determine the moisture content; b) at $550{ }^{\circ} \mathrm{C}$, for $4 \mathrm{~h}$, to estimate the organic matter content and c) at $1,000{ }^{\circ} \mathrm{C}$, for $2 \mathrm{~h}$, to determine the carbonate and hydroxide mass losses by employing an oven furnace and muffle, as needed [7].

The samples' swelling capacity was obtained by adding $1 \mathrm{~g}$ of the dry sample to deionized water in a $100 \mathrm{ml}$ graduated test tube and recording the volume after $24 \mathrm{~h}$ [8]. 
The $\mathrm{pH}$ was determined by mixing $10 \mathrm{~mL}$ of the wet mud sample with $25 \mathrm{~mL}$ of $\mathrm{KCl} 1.0 \mathrm{~mol} \mathrm{~L}$ 1. The mixture was stirred for $5 \mathrm{~min}$, let to stand for $1 \mathrm{~h}$ and then the measurement was done. All the physicochemical parameters were measured in triplicate.

\section{RESULTS AND DISCUSSION}

\subsection{Physicochemical characterization}

The results of physicochemical characterization are shown in table 1, and it shows that the $\mathrm{pH}$ of bentonite before the maturation process was around 7.8, whereas the montmorillonite presented a slightly lower $\mathrm{pH}$ value (around 7.3). The initial $\mathrm{pH}$ values of bentonite and montmorillonite were not significantly different from the $\mathrm{pH}$ value measured for the water from Águas de Lindóia (7.5), but it was lower than $\mathrm{pH}$ values of Poços de Caldas water (around 10).

Table 1: Physicochemical parameters: $\mathrm{pH}$, swelling values and percentages of moisture, LOI at $550{ }^{\circ} \mathrm{C}$ and LOI at $1000{ }^{\circ} \mathrm{C}$.

\begin{tabular}{|c|c|c|c|c|c|}
\hline & $\mathbf{p H}$ & Swelling (mL $\left.\mathbf{g}^{-1}\right)$ & Moisture (\%) & $\begin{array}{c}\text { LOI }(\%)^{\mathrm{a}} \text { at } \\
550{ }^{\circ} \mathrm{C}\end{array}$ & $\begin{array}{c}\text { LOI }(\%)^{\mathrm{b}} \text { at } \\
1000^{\circ} \mathrm{C}\end{array}$ \\
\hline BENTONITE & 7.8 & 12.2 & $13.93 \pm 0.01$ & $1.12 \pm 0.04$ & $4.53 \pm 0.03$ \\
\hline BAL & 7.8 & 16.7 & $11.1 \pm 0.5$ & $1.6 \pm 0.1$ & $3.7 \pm 0.1$ \\
\hline $\mathrm{BPC}$ & 8.3 & 10 & $19 \pm 3$ & $1.8 \pm 0.1$ & $3.21 \pm 0.05$ \\
\hline BPE & 8.2 & 12.7 & $12 \pm 1$ & $4.2 \pm 0.6$ & $4 \pm 1$ \\
\hline MONTMORILLONITE & 7.3 & 1.5 & $5.9 \pm 0.1$ & $7.9 \pm 0.4$ & $2.0 \pm 0.7$ \\
\hline MAL & 7.2 & All turbid & $2.77 \pm 0.06$ & $4.9 \pm 0.1$ & $4.3 \pm 0.1$ \\
\hline MPC & 7.7 & 9.7 & $8.70 \pm 0.06$ & $6.8 \pm 0.3$ & $2.2 \pm 0.2$ \\
\hline MPE & 7.4 & Not observed & $6.2 \pm 0.1$ & $9.8 \pm 0.4$ & $3 \pm 1$ \\
\hline
\end{tabular}

${ }^{\text {a }}$ Determined by calcination at $550{ }^{\circ} \mathrm{C}$, for $4 \mathrm{~h}$.

${ }^{\mathrm{b}}$ Determined by calcination at $1000{ }^{\circ} \mathrm{C}$, for $2 \mathrm{~h}$

The use of Águas de Lindóia water for bentonite and montmorillonite maturation did not cause a significant change in the $\mathrm{pH}$ in relation to non-matured clays. However, the clays matured with Poços de Caldas waters showed a slight increase in the $\mathrm{pH}$ value, whereas in the clays matured with Peruíbe seawater a slight increase could be observed only for bentonite. 
Reported values of $\mathrm{pH}$ in medicinal muds varies from 6.5 to $8.9[9,10,11,4,12]$. The $\mathrm{pH}$ values may influence the availability of the chemical elements adsorbed in the mineral grains composing the mud, and a small change in this parameter may affect ionic exchange properties during skin contact.

The results of the moisture content, by mass, in the bentonites and montmorillonite non-matured were $13.93 \%$ and $5.9 \%$ respectively. It is possible to note a decrease in the hydration degree in the bentonite and montmorillonite samples during the maturation process with Águas de Lindóia (11.1\% and $2.77 \%$, respectively) and Peruíbe (12\% and 6.2\%, respectively) water samples, and an increase when the Poços de Caldas water was used (19\% and $8.7 \%$, respectively). These results are smaller than the ones observed in the Peruíbe Black Mud [4], which varied from 34 to $73 \%$ and some clays used for pharmaceutical propose [13] whose values varies from 5 to $17 \%$, indicating that the water adsorption capacity is highly dependent on the origin and type of the clay mineral comprising the peloid.

The organic matter content found in medicinal muds may be related to its therapeutic properties [14] and is inversely correlated to its abrasiveness [15]. The content of organic matter in the bentonite and montmorillonite samples were $1.12 \%$ and $7.9 \%$, respectively.

An increase of organic matter content was observed in bentonite samples matured with Águas de Lindóia, Poços de Caldas and Peruíbe water (1.6, 1.8 and 4.2\%). However, for montmorillonite matured sample it is possible to note an increase of organic matter only for the one matured with the Peruíbe water sample (9.8\%), and a slight decrease in the sample matured with Águas de Lindóia $(4,9 \%)$ and Poços de Caldas $(6.8 \%)$ water samples.

The organic matter increase may be related to the biological activity of microorganisms present in the water or the ones already living in the clays that found in the water a good environment for growing. Literature values for organic matter content vary from 0.78 to $20 \%$ [3, 4].

Considering the weight $\%$ of LOI at $1000{ }^{\circ} \mathrm{C}$ values, a decrease is noted in bentonite matured with the three types of water (varying from $3.21 \%$ to $4 \%$ ) when compared with non-matured bentonite (4.53\%). These values were lower than bentonites from main Sardinia deposits presenting values varying from 5 to $15 \%[1,6]$. In montmorillonite samples, an increase was noted in matured samples (varying from $2.2 \%$ to $4 \%$ ) when compared with the non-matured ones (2\%). The bentonite and montmorillonite used here presented a low content of coordinated hydroxyl which characterizes 
clay minerals in its non-matured form, and the maturation process seems to decrease this amount in bentonite and increase it in montmorillonite.

Swelling power, measured in non-matured bentonites and montmorillonite samples to verify its interaction with a polar media has shown a large difference between them, with values of 12.2 $\mathrm{mL} \mathrm{g}^{-1}$ for bentonite and $1.5 \mathrm{~mL} \mathrm{~g}^{-1}$ for montmorillonite.

Comparing the peloid obtained by the maturation of bentonite with Águas de Lindóia water (BAL, $16.7 \mathrm{~mL} \mathrm{~g}^{-1}$ ), with the value obtained for the non-matured one a slight increase of swelling was observed. In these samples, it was possible to notice that in addition to the swelling, there was a great dispersion of colloidal particles in all the water used in the test, presenting a great interaction with the water. A slightly smaller swelling result was observed in the peloid maturated with Poços de Caldas water; however, in the peloid obtained with Peruíbe seawater, although it had presented a similar value, the dispersion of the particles was not observed as in the other samples. This should be related to the fact that the higher ionic strength of the seawater causes a decrease in the degree of clay swelling, according to [16].

The peloids obtained by the maturation of montmorillonite with Águas de Lindóia and Poços de Caldas water showed a significant increase in swelling when compared to non-matured one, indicating that the maturation process favored the intercalation of water between the grains of this clay. The same was not observed in the peloid obtained with Peruíbe seawater, in which a swelling was not observed, probably also due to the effect of the higher ionic strength of the sea water.

The swelling values measured in this study can be considered high proving the bentonite hydrophilicity [17]. In bentonites from Sardinian deposits, the swelling values varied from 6 to 39 $\mathrm{mL} \mathrm{g}^{-1}[6]$ and literature relates values varying from 15 to $25 \mathrm{~mL} \mathrm{~g}^{-1}$ for some other clays also used to pharmaceutical proposes $[4,13]$.

\subsection{Elemental characterization}

For methodology precision and accuracy verification of the results obtained by neutron activation analysis, the certified reference material Syenite Table Mountain (STM-2), from the United States Geological Survey (USGS) was analyzed. The results are shown in Table 2 and it can 
be observed that good precision and accuracy were obtained for the most of the elements with relative standard deviation (RSD) and relative error (RE) generally lower than $20 \%$.

The concentration of trace elements in bentonite and montmorillonite non-matured and the obtained peloids after three months of maturation are showed in Table 3, for those elements determined by INAA. As security is always a concern, in order to be used as therapeutic and cosmetic products in pelotherapy, peloids have to be completely characterized for impurity content, mainly for the potentially toxic elements, although there is no established official regulation about chemical composition, neither for the raw material nor for the matured form. Therefore, the obtained results were compared to consensus-based sediment quality guidelines (SQGs), for the elements As, $\mathrm{Cr}$ and $\mathrm{Zn}$, also shown in Table 3 [4].

Table 2: Values obtained in the certified reference material analysis for quality control of the results, in $\mu \mathrm{g} \mathrm{g}^{-1}$, except were indicated $\%$.

\begin{tabular}{|c|c|c|c|c|}
\hline & $\begin{array}{c}\text { STM } \\
\text { Certified Value }\end{array}$ & Analysis value & $\mathbf{R S D}^{\mathbf{a}}$ & $\mathbf{R E}^{\mathbf{b}}$ \\
\hline $\mathrm{Ba}$ & $639 \pm 61$ & $657 \pm 103$ & 15.61 & -2.75 \\
\hline $\mathrm{Ca}(\%)$ & $0.78 \pm 0.03$ & $0.53 \pm 0.07$ & 12.44 & 32.63 \\
\hline $\mathrm{Ce}$ & $256 \pm 23$ & $239 \pm 2$ & 0.97 & 5.36 \\
\hline Cs & $1.52 \pm 0.06$ & $1 \pm 0.2$ & 23.16 & 31.64 \\
\hline $\mathrm{Eu}$ & $3.45 \pm 0.25$ & $2.89 \pm 0.04$ & 1.24 & 16.21 \\
\hline $\mathrm{Fe}(\%)$ & $3.77 \pm 0.09$ & $3.97 \pm 0.06$ & 1.51 & -5.36 \\
\hline $\mathrm{Hf}$ & $27 \pm 0.8$ & $24.5 \pm 0.1$ & 0.58 & 9.11 \\
\hline $\mathrm{K}(\%)$ & $0.38 \pm 0.17$ & $4 \pm 1$ & 25.51 & -23.51 \\
\hline $\mathrm{La}$ & $154 \pm 11$ & $140.7 \pm 0.6$ & 0.44 & 8.63 \\
\hline $\mathrm{Lu}$ & $0.6 \pm 0.04$ & $0.55 \pm 0.01$ & 2.74 & 9.14 \\
\hline $\mathrm{Na}(\%)$ & $6.61 \pm 0.68$ & $6.17 \pm 0.09$ & 1.39 & 6.63 \\
\hline $\mathrm{Nd}$ & $81 \pm 4.8$ & $101 \pm 13$ & 13.05 & -24.82 \\
\hline $\mathrm{Rb}$ & $114 \pm 11$ & $139 \pm 9$ & 6.69 & -21.50 \\
\hline $\mathrm{Sm}$ & $12 \pm 0.9$ & $14.23 \pm 0.04$ & 0.29 & -18.59 \\
\hline $\mathrm{Ta}$ & $16 \pm 1.1$ & $24.5 \pm 0.1$ & 0.58 & -53.38 \\
\hline $\mathrm{Tb}$ & 1.38 & $0.99 \pm 0.04$ & 4.45 & 25.42 \\
\hline Th & $27 \pm 5$ & $32.1 \pm 0.4$ & 1.18 & -18.98 \\
\hline $\mathrm{U}$ & 7.6 & $12 \pm 1$ & 8.61 & -55.63 \\
\hline $\mathrm{Yb}$ & $4.2 \pm 0.8$ & $3.2 \pm 0.1$ & 1.85 & 23.89 \\
\hline $\mathrm{Zn}$ & $223 \pm 19$ & $193 \pm 9$ & 4.90 & 13.43 \\
\hline
\end{tabular}


The SQG values, threshold effect concentration (TEC) and probable effect concentration (PEC), provide a reliable basis for assessing sediment quality conditions in aquatic ecosystems for some potentially toxic elements and the results of the bentonite elemental concentrations revealed that none of them is higher than the PEC and TEC values. Otherwise, $\mathrm{Cr}$ and $\mathrm{Zn}$ concentration in nonmatured montmorillonite and in their peloids presented concentrations higher than TEC, except for Zn in the one matured with Água de Lindóia water.

Upon comparing the bentonite with the montmorillonite non-matured samples, it is possible to note that in the montmorillonite, the elements $\mathrm{Co}, \mathrm{Cr}, \mathrm{Cs}$, and $\mathrm{Zn}$ showed higher concentrations, the concentrations of $\mathrm{Fe}, \mathrm{K}, \mathrm{Rb}$, and $\mathrm{Sc}$ are slightly higher and that the elements $\mathrm{As}, \mathrm{Br}, \mathrm{Hf}, \mathrm{Lu}, \mathrm{Na}, \mathrm{Sb}$, $\mathrm{Se}, \mathrm{Sm}, \mathrm{Ta}, \mathrm{Tb}, \mathrm{Th}$, and $\mathrm{Zr}$ appeared in smaller concentrations. 
Table 3: Trace element concentrations, in $\mu \mathrm{g} \mathrm{g}^{-1}$, except where indicated $\%$, in bentonite samples matured in Águas de Lindóia (BAL), Poços de Caldas (BPC) and Peruíbe (BPE) and montmorillonite matured in Águas de Lindóia (MAL) Poços de Caldas (MPC) and Peruíbe (MPE) and the threshold effect concentration (TEC) and probable effect concentration (PEC) values [18].

\begin{tabular}{cccccccc}
\hline & As & $\mathbf{C r}$ & $\mathbf{Z n}$ & $\mathbf{B a}$ & $\mathbf{B r}$ & $\mathbf{C a}(\boldsymbol{\%})$ & $\mathbf{C e}$ \\
\hline BENTONITE & $9.3 \pm 0.1$ & $7.2 \pm 0.2$ & $90 \pm 1$ & $316 \pm 11$ & $7.06 \pm 0.08$ & $1.13 \pm 0.02$ & $98.6 \pm 0.4$ \\
BAL & $9.1 \pm 0.1$ & $7.1 \pm 0.2$ & $85 \pm 1$ & $351 \pm 11$ & $9.47 \pm 0.08$ & $1.08 \pm 0.02$ & $112.7 \pm 0.4$ \\
BPC & $8.6 \pm 0.2$ & $7.1 \pm 0.3$ & $92 \pm 2$ & $403 \pm 24$ & $4.9 \pm 0.3$ & $0.55 \pm 0.01$ & $104 \pm 2$ \\
BPE & $7.9 \pm 0.2$ & $4.3 \pm 0.1$ & $102 \pm 2$ & $396 \pm 22$ & $775 \pm 2$ & $0.63 \pm 0.01$ & $80 \pm 2$ \\
MONTMORILLONITE & $6 \pm 0.1$ & $71 \pm 1$ & $207 \pm 3$ & $543 \pm 21$ & $1.05 \pm 0.07$ & $2.16 \pm 0.05$ & $93.4 \pm 0.4$ \\
MAL & $6 \pm 0.1$ & $72 \pm 2$ & $97 \pm 3$ & $401 \pm 22$ & $1.36 \pm 0.07$ & $1.69 \pm 0.06$ & $92.9 \pm 2.1$ \\
MPC & $2.8 \pm 0.1$ & $73 \pm 1$ & $230 \pm 6$ & $465 \pm 29$ & $4 \pm 0.1$ & $1.05 \pm 0.04$ & $86 \pm 2$ \\
MPE & $2.2 \pm 0.1$ & $59 \pm 1$ & $167 \pm 4$ & $453 \pm 20$ & $229.8 \pm 0.7$ & $1.88 \pm 0.06$ & $78 \pm 2$ \\
TEC/PEC & $9.79 / 33$ & $44.3 / 111$ & $121 / 459$ & & & & \\
\hline BENTONITE & $\mathbf{C o}$ & $\mathbf{C s}$ & $\mathbf{E u}$ & $\mathbf{F e}(\boldsymbol{\%})$ & $\mathbf{H f}$ & $\mathbf{K}(\boldsymbol{\%})$ & $\mathbf{L a}$ \\
BAL & $1.33 \pm 0.01$ & $0.5 \pm 0.1$ & $0.737 \pm 0.007$ & $2.72 \pm 0.02$ & $7.98 \pm 0.02$ & $0.51 \pm 0.09$ & $54.4 \pm 0.7$ \\
BPC & $1.44 \pm 0.02$ & $0.91 \pm 0.04$ & $0.74 \pm 0.01$ & $2.66 \pm 0.02$ & $7.89 \pm 0.06$ & & $51.5 \pm 1$ \\
BPE & $1.36 \pm 0.02$ & $0.5 \pm 0.04$ & $0.61 \pm 0.01$ & $2.16 \pm 0.02$ & $6.35 \pm 0.05$ & $0.9 \pm 0.2$ & $39.6 \pm 0.7$ \\
\hline MAL & $17.5 \pm 0.08$ & $11.44 \pm 0.09$ & $1.429 \pm 0.009$ & $4.88 \pm 0.04$ & $3.62 \pm 0.02$ & $3.2 \pm 0.4$ & $47 \pm 0.9$ \\
MPC & $17.2 \pm 0.1$ & $10 \pm 0.1$ & $1.36 \pm 0.04$ & $4.91 \pm 0.04$ & $3.13 \pm 0.03$ & $1.6 \pm 0.1$ & $49.6 \pm 1$ \\
MPE & $14.2 \pm 0.1$ & $13.4 \pm 0.8$ & $1.76 \pm 0.03$ & $4.88 \pm 0.03$ & $1.72 \pm 0.02$ & $2.8 \pm 0.3$ & $46.9 \pm 0.9$ \\
MONTMORILLONITE & $14.9 \pm 0.1$ & $9.9 \pm 0.6$ & $1.45 \pm 0.02$ & $3.82 \pm 0.03$ & $2.69 \pm 0.02$ & $1.8 \pm 0.2$ & $39 \pm 0.8$ \\
\hline
\end{tabular}

\footnotetext{
${ }^{a}$ Threshold effect concentration

${ }^{\mathrm{b}}$ Probable effect concentration
} 
Table 3: Continuation.

\begin{tabular}{cccccccc}
\hline & Lu & Na & Nd & $\mathbf{R b}$ & Sb & Sc & Se \\
\hline BENTONITE & $0.521 \pm 0.006$ & $1.47 \pm 0.02$ & $48 \pm 1$ & $14.5 \pm 0.4$ & $1.23 \pm 0.02$ & $5.49 \pm 0.02$ & $1.5 \pm 0.1$ \\
BAL & $0.611 \pm 0.005$ & $1.25 \pm 0.02$ & $62 \pm 1$ & $13.7 \pm 0.4$ & $1.42 \pm 0.02$ & $6.3 \pm 0.02$ & $1.7 \pm 0.1$ \\
BPC & $0.589 \pm 0.015$ & $1.22 \pm 0.02$ & $47 \pm 2$ & $20.4 \pm 0.9$ & $1.19 \pm 0.02$ & $6.27 \pm 0.02$ & $1.4 \pm 0.2$ \\
BPE & $0.465 \pm 0.012$ & $5.43 \pm 0.09$ & $24 \pm 2$ & $12.6 \pm 0.6$ & $1.02 \pm 0.02$ & $4.86 \pm 0.02$ & $1.1 \pm 0.2$ \\
MONTMORILLONITE & $0.39 \pm 0.007$ & $0.13 \pm 0.002$ & $48 \pm 1$ & $195 \pm 2$ & $0.59 \pm 0.02$ & $17.11 \pm 0.05$ & $1.4 \pm 0.1$ \\
MAL & $0.34 \pm 0.01$ & $0.12 \pm 0.003$ & $44 \pm 5$ & $208 \pm 6$ & $0.61 \pm 0.03$ & $17.52 \pm 0.06$ & $1.4 \pm 0.3$ \\
MPC & $0.289 \pm 0.01$ & $0.68 \pm 0.01$ & $35 \pm 3$ & $219 \pm 7$ & $0.56 \pm 0.02$ & $18.8 \pm 0.1$ & \\
MPE & $0.325 \pm 0.009$ & $3.38 \pm 0.05$ & $49 \pm 4$ & $180 \pm 5$ & $0.14 \pm 0.01$ & $14.86 \pm 0.05$ & $0.8 \pm 0.2$ \\
\hline BENTONITE & $\mathbf{S m}$ & $\mathbf{T a}$ & $\mathbf{T b}$ & $\mathbf{T h}$ & $\mathbf{U}$ & $\mathbf{Y b}$ & $\mathbf{Z r}$ \\
BAL & $10.3 \pm 0.3$ & $2.4 \pm 0.03$ & $1.5 \pm 0.05$ & $37.4 \pm 0.1$ & $13 \pm 0.2$ & $1.83 \pm 0.02$ & $302 \pm 14$ \\
BPC & $21 \pm 1$ & $2.72 \pm 0.05$ & $1.39 \pm 0.05$ & $41 \pm 2$ & $14 \pm 0.5$ & $3.6 \pm 0.2$ & $285 \pm 11$ \\
BPE & $14.9 \pm 0.8$ & $2.14 \pm 0.04$ & $1.02 \pm 0.03$ & $31 \pm 1$ & $10.6 \pm 0.4$ & $2.9 \pm 0.1$ & $250 \pm 9$ \\
MORILLONITE & $8.3 \pm 0.2$ & $1.08 \pm 0.02$ & $0.72 \pm 0.03$ & $18.03 \pm 0.06$ & $2.9 \pm 0.1$ & $2.38 \pm 0.05$ & $225 \pm 23$ \\
MAL & $8 \pm 0.2$ & $1.15 \pm 0.03$ & $0.83 \pm 0.05$ & $16.73 \pm 1.09$ & $6 \pm 0.2$ & $1.6 \pm 0.1$ & $108 \pm 33$ \\
MPC & $7.4 \pm 0.2$ & $1.39 \pm 0.04$ & $0.35 \pm 0.07$ & $17.3 \pm 0.7$ & $5.7 \pm 0.2$ & $1.7 \pm 0.1$ & $267 \pm 29$ \\
MPE & $6.5 \pm 0.2$ & $0.75 \pm 0.06$ & $0.58 \pm 0.04$ & $14.8 \pm 0.6$ & $4.4 \pm 0.2$ & $1.8 \pm 0.1$ & $165 \pm 12$ \\
\hline
\end{tabular}


Torrecilha, et. Al. • Braz. J. Rad. Sci. • 2019

Table 4: Trace element concentrations, in $\mu \mathrm{g} \mathrm{L}{ }^{-1}$, except $\mathrm{Fe}, \mathrm{K}$ and $\mathrm{Na}\left(\mathrm{mg} \mathrm{L}^{-1}\right)$ in Águas de Lindóia and Poços de Caldas water.

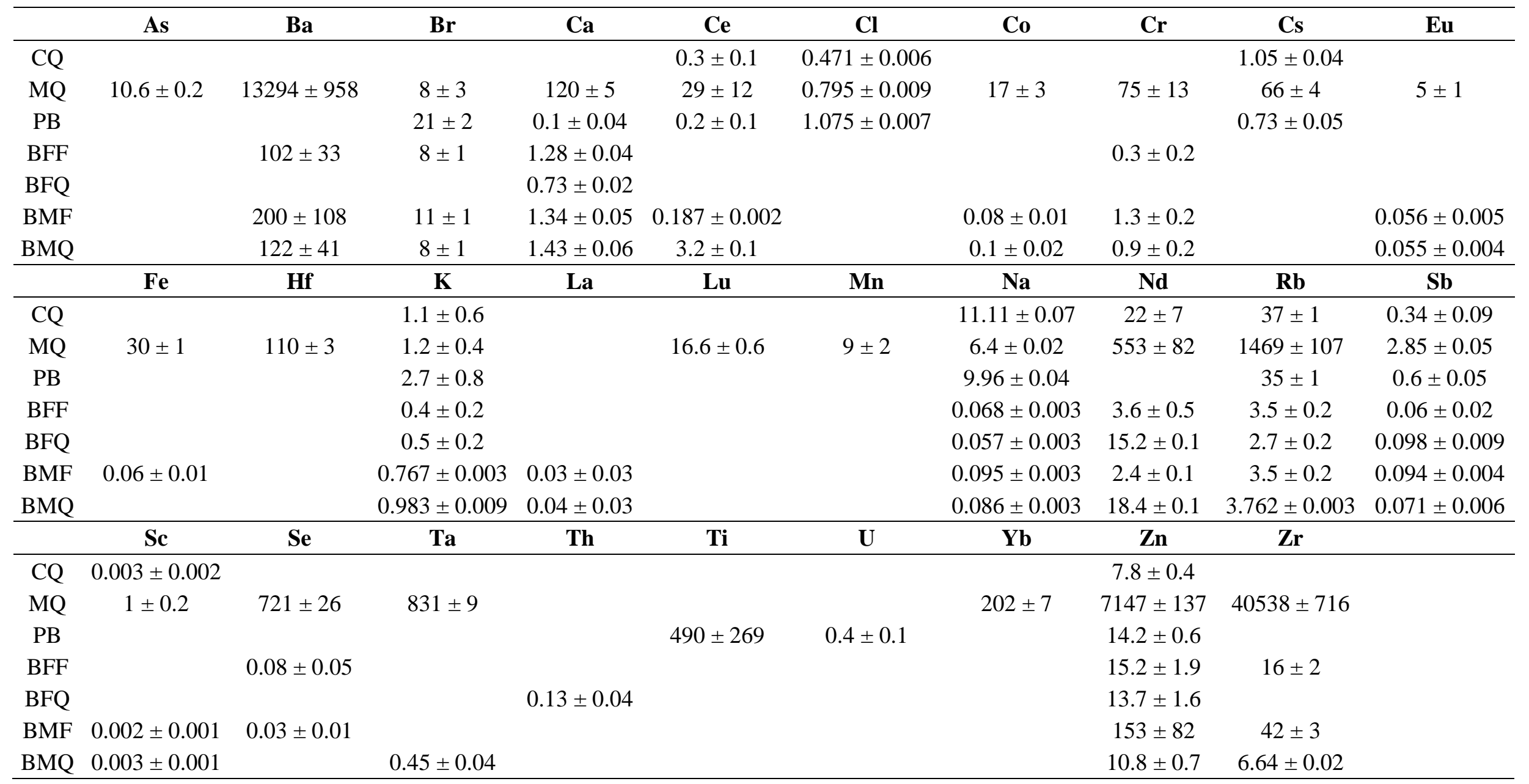


Water samples from Águas de Lindóia (BFF, BFQ, BMF, BMQ) and Poços de Caldas (CQ, MQ, PB) were also analyzed, and the results are shown in table 4. Those water samples presented results that were agreeable to each other, with very low concentrations and in the same order of magnitude, but Mariquinha spring (MQ) presented much higher concentrations for all the determined elements in relation to the other springs. This is probably due to the rock percolated by the water of MQ spring.

Concerning the bentonite peloid obtained with the three different types of water, it can be noted that the maturation process favored a slight increase in the concentration of the elements $\mathrm{Ba}$, Co, $\mathrm{Cs}$, and $\mathrm{K}$. The concentration of Fe, Hf, Lu, Nd, Rb, Sb, Sc, if, Sm, Ta, Tb, Th, U, and Zn was not changed after maturation. For the elements As and $\mathrm{Cr}$, it can be noted that the concentrations were slightly lower in the peloid matured with Peruíbe water $\left(7.9 \mu \mathrm{g} \mathrm{g}^{-1}\right.$ and $\left.4.3 \mu \mathrm{g} \mathrm{g}^{-1}\right)$ when compared with the peloid obtained with Águas de Lindóia $\left(9.1 \mu \mathrm{g} \mathrm{g}^{-1}\right.$ and $\left.7.1 \mu \mathrm{g} \mathrm{g}^{-1}\right)$ and Poços de Caldas (8.6 $\mu \mathrm{g} \mathrm{g}^{-1}$ and $7.1 \mu \mathrm{g} \mathrm{g}^{-1}$ ) water. In the bentonite peloid obtained with the Peruíbe seawater, the concentrations of $\mathrm{Na}$ and $\mathrm{Zn}$ appear larger $\left(5.43 \mu \mathrm{g} \mathrm{g}^{-1}\right.$ and $250 \mu \mathrm{g} \mathrm{g}^{-1}$, respectively) when compared with the peloid obtained by the maturation with Águas de Lindóia and Poços de Caldas water. A significant difference was noted in the increase of $\mathrm{Br}$ and $\mathrm{Na}$ concentration by the maturation with sea water in both clays. The $\mathrm{Br}$ concentration in the bentonite after maturation increased from $7.06 \mu \mathrm{g} \mathrm{g}^{-1}$ to $775 \mu \mathrm{g} \mathrm{g}^{-1}$ and in the montmorillonite increased from $1.05 \mu \mathrm{g} \mathrm{g}^{-1}$ to $229.8 \mu \mathrm{g} \mathrm{g}^{-1}$. For the element $\mathrm{Na}$, the concentration in the bentonite after maturation increased from 1.47 to $5.43 \%$ and in the montmorillonite, from 0.13 to $3.38 \%$. The concentration of Ca in bentonite remains the same with maturation using Águas de Lindóia water, however, a slight decrease of the concentration of this element is noticed in peloids obtained by maturation with Poços de Caldas and Peruíbe water. However, in montmorillonite the Ca concentration decreased after the maturation process with the three types of water.

Compared with the values for elements found in peloids from European spas and [19] and Peruibe Black Mud [4], it is observed that the concentrations of $\mathrm{Br}, \mathrm{Co}, \mathrm{Cr}, \mathrm{Cs}, \mathrm{Na}$, and $\mathrm{Rb}$ are lower and the concentrations of $\mathrm{Ca}, \mathrm{Sb}, \mathrm{Sm}, \mathrm{Ta}, \mathrm{Tb}, \mathrm{Th}$, and $\mathrm{U}$ are higher in these bentonite and montmorillonite samples. 


\section{CONCLUSION}

This study proposed to characterize the elemental composition of peloids artificially obtained by the maturation process of mixing bentonite and montmorillonite with mineral-medicinal water from Águas de Lindóia, Poços de Caldas and seawater from Peruíbe.

The use of Águas de Lindóia water for both bentonite and montmorillonite did not cause any significant change in $\mathrm{pH}$ in relation to non-matured clays. However, the peloids matured with Poços de Caldas water showed a slight increase in the $\mathrm{pH}$ value while the one matured with Peruíbe water showed a slight increase only for the maturation of bentonite.

It was possible to note an increase in the organic matter content in bentonite samples matured with all three types of water. For montmorillonite matured samples, it was possible to note an increase of organic matter only in the sample matured with Peruíbe seawater. The increase of organic matter may be related to the biological activity of microorganisms present in the water or the ones already living in the clays that found in the water a good environment for growing.

Water samples from Águas de Lindóia and Poços de Caldas were also analyzed and showed concordant results, with very low concentrations at the same order of magnitude. Only the MQ spring presented much higher concentrations for all elements in relation to the other water samples analyzed, probably due to the rock in which the water of the MQ source percolates.

The non-matured montmorillonite presented slightly higher concentrations of the elements Eu, $\mathrm{Fe}, \mathrm{K}, \mathrm{Rb}$ and $\mathrm{Sc}$ and much higher concentrations the elements $\mathrm{Co}, \mathrm{Cr}$, Cs and $\mathrm{Zn}$ than non-matured bentonite. The elements As, Br, Hf, Lu, EM, Sb, Hf, Sm, Ta, Tb, Th, and Zr were at higher concentrations in non-matured bentonite.

A significant increase in $\mathrm{Br}$ and $\mathrm{Na}$ concentration was noted in the samples matured with seawater from Peruíbe in both types of clay. A slight decrease in Ca concentration was noticed in the peloids obtained by the maturation of bentonite with Poços de Caldas and Peruíbe water and no difference was observed by the maturation using Águas de Lindóia water. In montmorillonite samples, the Ca concentration decreases after the maturation process with the three types of water. According to the results obtained in this work, it is possible to note that bentonite matured in seawater presented the best response to the production of a therapeutic peloid, because it presents a 
greater increase of organic matter after the maturation process when compared with montmorillonite and maturation of bentonite in other waters as well as a $\mathrm{pH}$ increase.

\section{REFERENCES}

[1] LEGIDO, J. L.; MEDiNA, C.; MOURElle, M. L.; CARRETERO, M. I.; POZO, M. Comparative study of the cooling rates of bentonite, sepiolite and common clays for their use in pelotherapy. App. Clay Sc., v. 36, p.148-160, 2007.

[2] MOSSO, M.; DE LA ROSA, M.; DÍAZ, M. Microbiología del manantial de águas minero medicinales y de los lodos del balneario de Arnedillo, In: ACADEMIA NACIONAL DE FARMACIA, 1998, Madrid, p.23-28.

[3] FERNÁNDEZ-GONZÁLEZ, M. V.; MARTÍN-GARCÍA, J. M.; DELGADO, G.; PÁRRAGA, J.; CARRETERO, M. I.; DELGADO, R. Physical properties of peloids prepared with medicinal mineral waters from Lanjarón Spa (Granada, Spain). Appl. Clay Sci, v. 135, p. 465-474, 2017.

[4] SILVA, P. S. C.; TORRECILHA, J. K.; GOUVEA, P. F. M.; MÁDUAR, M. F. S.; OLIVEIRA, M. B.; SCAPIN, M. A. Chemical and radiological characterization of Peruíbe Black Mud. App. Clay Sci, v. 118, p. 221-230, 2015.

[5] VENIALE, F.; BARBERIS, E.; CARCANGIU, G.; MORANDI, N.; SETTI, M.; TESSIER, D. Formulation of muds for pelotherapy: effects of "maduration" by different mineral waters. Appl. Clay Sci. v. 25, p. 135-148, 2004.

[6] CARA, S.; CARCANGiU, G.; PADAlinO, G.; PAlOMB, M.; TAMANINI, M. The bentonites in pelotherapy: chemical, mineralogical and technological properties of materials from Sardinia deposits (Italy). Appl. Clay Sci, v. 16, p.117-124, 2000.

[7] DEAN, W. E. Determination of carbonate and organic matter in calcareous sediments and sedimentary rocks by loss on ignition: comparison with other methods. J. Sediment. Petrol, v. 44, p.242-248, 1974. 
[8] FOSTER, M. D.; SURVERY, U. S. G.; WASHINGTON, D. C. Geochemical studies of clay minerals: II — relation between ionic substitution and swelling in montmorillonites. Am. Mineral, v. 38, p. 994-1006, 1953.

[9] CARRETERO, M.I.; POZO, M.; LEGIDO, J. L.; FERNÁNDEZ-GONZÁLEZ, M.V.; DELGADO, R.; GÓMEZ, I.; ARMIJO, F.; MARAVER, F. Assessment of three Spanish clays for their use in pelotherapy. Appl. Clay Sci, v. 99, p. 131-143, 2014.

[10] KARAKAYA, M. C.; KARAKAYA, N.; SARIOĞLAN, S.; KORAL, M. Some properties of thermal muds of some spas in Turkey. Appl. Clay Sci, p. 48, v. 531-537, 2010.

[11] KNORST-FOURAN, A.; CASÁS, L. M.; LEGIDO, J. L.; COUSSINE, C.; BESSIÈRES, D.; PLANTIER, F.; LAGIÈRE, J.; DUBOURG, K. Influence of dilution on the thermophysical properties of Dax peloid (TERDAX®). Thermochim. Acta, v. 539 (10), p. 34-38, 2012.

[12] MUÑOZ, M. S.; RODRÍGUEZ, C. M.; RUDNIKAS, A. G.; RIZO, O. D.; MARTÍNEZSANTOS, M.; RUIZ-ROMERA, E.; CASTILlO, J. R. F.; PÉREZ-GRAMATGES, A.; MARTÍNEZ-VILLEGAS, N. V.; PADILLA, D. B.; DÍAZ, R. H.; GONZÁLEZ-HERNÁNDEZ, P. Physicochemical characterization, elemental speciation and hydrogeochemical modeling of river and peloid sediments used for therapeutic uses. Appl. Clay Sci, v. 104, p. 36-47, 2015.

[13] LÓPEZ-GALINDO, A.; VISERAS, C.; CEREZO, P. Compositional, technical and safety specifications of clays to be used as pharmaceutical and cosmetic products. Appl. Clay Sci, v. 36, p. 51-63, 2007.

[14] GOMES, C.; CARRETERO, M. I.; POZO, M.; MARAVER, F.; CANTISTA, P.; ARMIJO, F.; LEGIDO, J.L.; TEIXEIRA, F.; RAUTUREAU, M.; DELGADO, R. Peloids and pelotherapy: historical evolution, classification and glossary. Appl. Clay Sci. v. 75-76, p. 28-38, 2013.

[15] POZO, M.; CARretero, M. I.; MARAVER, F.; POZO, E.; GÓMEZ, I.; ARMiJO, F.; RUBÍ, J. A. M. Composition and physico-chemical properties of peloids used in Spanish spas: a comparative study. Appl. Clay Sci. v. 83-84, p. 270-279, 2013. 
[16] CARDOSO, J. J. B.; LOPES, R. T.; NETO, J. C. Q. Estudo do inchamento de bentonita sódicas e avaliação do desempenho de inibidores pela difração de raios $\mathrm{X}$, In: INTERNATIONAL NUCLEAR ATLANTIC CONFERENCE, 2005, Santos. Annals... Santos: Comissão Nacional de Energia Nuclear, 2005. p. 1-6.

[17] HUANG, W.; WANG, Y.; QIU, Z.; LEONG, Y. -K.; CUI, M.; ZHONG, H. Synthesis and characterization of strong hydrophobic bentonite. Mater. Res. Innovations, v. 19, p. 428-434, 2015.

[18] MACDONALD, D. D.; INGERSOLL, G.; BERGER, T. A. Development and evaluation of consensus- based sediment quality guidelines for freshwater ecosystems. Arch. Environ. Contam. Toxicol. v. 39, p. 20-31, 2000.

[19] QUINTELA, A.; TERROSO, D.; SILVA, E. F.; ROCHA, F. Certification and quality criteria of peloids used for therapeutic purposes. Clay Miner. v. 47, p. 441-451, 2012. 